\title{
Expression of miRNAs in ovine fetal gonads: potential role in gonadal differentiation
}

\author{
Katie J Torley ${ }^{1 \dagger}$, Juliano C da Silveira ${ }^{1 \dagger}$, Peter Smith ${ }^{2}$, Russell V Anthony ${ }^{1}$, DN Rao Veeramachaneni ${ }^{1}$, \\ Quinton A Winger ${ }^{1}$, Gerrit J Bouma ${ }^{1 *}$
}

\begin{abstract}
Background: Gonadal differentiation in the mammalian fetus involves a complex dose-dependent genetic network. Initiation and progression of fetal ovarian and testicular pathways are accompanied by dynamic expression patterns of thousands of genes. We postulate these expression patterns are regulated by small non-coding RNAs called microRNAs (miRNAs). The aim of this study was to identify the expression of miRNAs in mammalian fetal gonads using sheep as a model.

Methods: We determined the expression of 128 miRNAs by real time PCR in early-gestational (gestational day (GD) 42) and mid-gestational (GD75) sheep ovaries and testes. Expression data were further examined and validated by bioinformatic analysis.

Results: Expression analysis revealed significant differences between ovaries and testes among 24 miRNAs at GD42, and 43 miRNAs at GD75. Bioinformatic analysis revealed that a number of differentially expressed miRNAs are predicted to target genes known to be important in mammalian gonadal development, including ESR1, CYP19A1, and SOX9. In situ hybridization revealed miR-22 localization within fetal testicular cords. As estrogen signaling is important in human and sheep ovarian development, these data indicate that miR-22 is involved in repressing estrogen signaling within fetal testes.
\end{abstract}

Conclusions: Based on our results we postulate that gene expression networks underlying fetal gonadal development are regulated by miRNAs.

\section{Background}

Genetic sex in mammals is determined at the time of fertilization; fertilization of eggs with $\mathrm{X}$ or Y-bearing sperm will yield XX (female) or XY (male) embryos, respectively. Normally, distinct genetic pathways will subsequently direct undifferentiated genital ridges in XX and $\mathrm{XY}$ fetuses to develop into fetal ovaries or fetal testes, respectively. Mammalian fetal gonadal differentiation is a developmental process involving a dose dependent balance between promoting and antagonizing factors. That is, the testicular developmental pathway involves genetic networks both promoting testis development and preventing ovarian development and vice versa $[1,2]$. Critical genes involved in initiation of the

\footnotetext{
* Correspondence: Gerrit.Bouma@colostate.edu

+ Contributed equally

${ }^{1}$ Animal Reproduction and Biotechnology Laboratory, Department of Biomedical Sciences, Colorado State University, Fort Collins, CO 80523, USA Full list of author information is available at the end of the article
}

testicular and ovarian developmental pathways are the Y-linked gene, Sry (sex determining region of chromosome Y) [3,4], and Rspo1 (R-spondin homolog), Wnt4 (wingless-related MMTV integration site 4) and $\beta$-catenin [5,6], respectively. These genes are expressed in the somatic support cells of the fetal gonads directing differentiation of the supporting cell lineages, i.e., Sertoli cells in the testis and granulosa cells in the ovary [5-9]. Genome profiling experiments further have demonstrated that both testicular and ovarian developmental pathways are characterized by dynamic expression patterns of thousands of genes [10-14]. How the expression and function of these genes are regulated is unknown.

Small non-coding RNA molecules called microRNAs (miRNAs) are $\sim 22$ nt cytoplasmic RNAs that regulate gene expression and function in many tissues [15-17]. MiRNAs are transcribed by RNA polymerase II generating hairpin loop containing structures called primarymiRNAs which are cleaved by the endonuclease RNAse

\section{Biomed Central}


III DROSHA and its partner DGCR8, yielding a 70-90 nt hairpin stem-loop precursor miRNA (pre-miRNA). Pre-miRNAs are exported into the cytoplasm by Exportin-5 and processed by DICER1, yielding a $\sim 22 \mathrm{nt}$ mature miRNA. MiRNAs recognize transcript targets through base-pairing to the 3'-untranslated region (UTR), and are able to repress translation or cause degradation, depending upon sequence complementarity. Previous work has demonstrated that miRNA sequences are highly conserved across species and can be expressed in a tissue specific manner [18]. The importance of miRNAs in reproduction was demonstrated using transgenic mouse models [19-24]. Conditional gene targeting approaches demonstrated that Dicer is important for primordial germ cell and spermatogonial proliferation $[19,20]$, Sertoli cell function [21], and development of the oviducts and uteri [22-24].

The above-mentioned studies indicate that miRNAs are important for reproductive development and function, but do not indicate which miRNAs. MiRNA cloning experiments have demonstrated differences in expression profiles between ovaries and testis of adult mice [25], and analysis of a bovine fetal ovarian miRNA library revealed miRNAs predominantly expressed in fetal ovaries compared to somatic tissue pools [26]. Little is known about the expression of miRNAs during fetal gonadal development in mammals. Based on the observation that fetal ovarian and testicular development involves coordinate expression of thousands of genes, we predict that miRNAs are expressed and are involved in regulating gene expression and function during fetal gonadal development.

The aim of this study was to identify the expression of miRNAs in mammalian fetal gonads using the ovine as a model. In addition, expression levels were examined of a number of key genes involved in fetal ovarian (ESR1, ESR2, CYP19, FST, and WNT4) and testicular development (SOX9) as potential target genes of miRNAs. The study of gonadal differentiation and reproductive development in sheep provides both insight into human gonadal development, and a better understanding of reproductive development of economically important livestock species.

\section{Methods}

\section{Sheep breeding and tissue collection}

All experimental procedures using animals were approved by the Colorado State University Animal Care and Use Committee. Estrous cycles of twenty-four ewes were synchronized using prostaglandin F2 $\alpha$ ( $5 \mathrm{mg}$; Lutalyse; Pfizer Animal Health), and ewes and rams were mated and kept together for twelve to twenty-four hours to ensure successful mating (up to 4 ewes with one ram, and the ram replaced with a new ram after $\sim 12$ hours). Around gestational day (GD) 40, pregnancy status was confirmed by ultrasonography.

Tissues were collected at either GD42 or 75 (term is $\sim 150$ days). GD42 corresponds to the period of testicular cord differentiation and ovigerous cord development in XY and XX gonads respectively, whereas GD75 coincides with primordial follicle formation in the ovary $[27,28]$. Ewes were taken off feed and water at least twelve hours before necropsy to facilitate unhindered tissue collection. Ewes were euthanized by intrajugular injection of sodium pentobarbital $(90 \mathrm{mg} / \mathrm{kg})$. Each fetus was measured crown to rump and lengths were used to estimate and confirm gestational age. Fetal gonads were removed and one was homogenized in $350 \mu \mathrm{l}$ of RLT Plus lysis buffer (RNeasy Plus Mini Kit, Qiagen) and the other was fixed in 4\% paraformaldehyde (PFA; GD42) or Bouin's fixative (GD75). Gonads used for RNA isolation were stored at $-80^{\circ} \mathrm{C}$. Gonads for histology were fixed overnight, transferred to $70 \%$ ethanol, and stored at $4{ }^{\circ} \mathrm{C}$ until embedded in paraffin.

\section{Fetal sheep sex genotyping}

Genetic sex was determined by PCR genotyping using fetal tail tissue lysate, and ovine $S R Y$ primers (Forward primer: 5'- CATTGTGTGGTCTCGTGAACG-3'; Reverse primer: 5'-GTCTCGGTGTATAGCTAGTAG-3') designed based on the ovine SRY sequence (GenBank Accession number $\mathrm{Z} 30265)$. Polymerase chain reaction was run using the following program: $95^{\circ} \mathrm{C}-3$ minutes; $60^{\circ} \mathrm{C}-5$ minutes; $72^{\circ} \mathrm{C}$ - 5 minutes $\left(1\right.$ cycle); $95^{\circ} \mathrm{C}-30$ seconds, $58^{\circ} \mathrm{C}-30$ seconds, $72^{\circ} \mathrm{C}-45$ seconds ( 35 cycles); and $72^{\circ} \mathrm{C}-5$ minutes. PCR products were run on a $2 \%$ agarose gel, and visualized using ethidium bromide.

\section{Total RNA isolation}

Total RNA, including miRNAs, was isolated using the RNeasy Plus Mini kit (Qiagen), according to the manufacturer's instructions. To ensure the small RNA fraction was retained, the first washing step with RW1 buffer was replaced by $100 \%$ ethanol (1.5x volume of the tissue lysate) according to manufacturer's specification. RNA was eluted in $40 \mu \mathrm{l}$ RNAse-free water, and treated with DNAse $(4 \mu \mathrm{l} 10 \times$ DNAse buffer and $1 \mu \mathrm{l}$ DNAse-I (Ambion)) to eliminate genomic DNA contamination. RNA concentration and purity were determined using the NanoDrop ND-1000 spectrophotometer. Samples were then stored at $-80^{\circ} \mathrm{C}$.

\section{Reverse Transcription of miRNAs}

Small non-coding RNAs were reverse transcribed using the QuantiMirTM RT kit (Systems Biosciences (SBI), Mountain View, CA) according to the manufacturer's instructions. Briefly, 500 ng of total RNA including the small RNA fraction was anchor-tailed with polyA by 
incubating RNA, $5 \times$ PolyA Buffer, $25 \mathrm{mM} \mathrm{MnCl}$, $5 \mathrm{mM}$ ATP, and polyA polymerase at $37^{\circ} \mathrm{C}$ for $30 \mathrm{~min}$ utes. Oligo dT adaptors were annealed at $60^{\circ} \mathrm{C}$ for 5 minutes, and reverse transcription first strand synthesis reaction was carried out by incubating the samples at $42^{\circ} \mathrm{C}$ for 60 minutes followed by $95^{\circ} \mathrm{C}$ for 10 minutes.

\section{Real-time PCR expression of conserved miRNAs in fetal gonads}

A preliminary experiment was conducted to examine the expression of 211 miRNAs whose mature sequence was identical in human, mouse, bovine and/or goat [29]. Of these 211 miRNAs, 128 were selected that were expressed (arbitrarily set at crossing-point value $(\mathrm{Cp})<$ 37) according to real time RT-PCR analysis, and showed a single melt peak following dissociation curve analysis. The relative expression of 128 mature miRNAs (see Additional file 1, Table S1) in fetal sheep gonads was assessed using real-time PCR using a custom designed primer plate containing the mature miRNA sequences as a forward primer (SBI).

Each analysis was performed in $6 \mu \mathrm{l}$ reactions containing $2 \times$ SYBR Green I master mix (Roche Applied Sciences), $10 \mu \mathrm{M}$ Universal reverse primer and miRNA specific forward primer (SBI), and $1 \mu \mathrm{l}$ cDNA. Real time PCR was conducted using the LightCycler480 PCR system (Roche Applied Sciences) with 384-well plates each containing 3 biological replicates. The PCR cycle conditions were as follows: $95^{\circ} \mathrm{C}$ for 5 minutes, 45 cycles of $95^{\circ} \mathrm{C}$ for 10 seconds, $60^{\circ} \mathrm{C}$ for 15 seconds, and $72^{\circ} \mathrm{C}$ for 15 seconds followed by a melt curve analysis to confirm amplification of single cDNA products. Fold change and statistically significant differences of the 128 miRNAs were determined using Global Pattern Recognition (GPR) software v2.0 [30,31]. Using GPR, miRNAs considered significantly different were those with a GPR score of 0.400 or greater [31], whereas fold changes were calculated based on 10 normalizers (miRNAs in the data set that are expressed and not significantly different).

\section{Reverse transcription of mRNAs}

Messenger RNA was reverse transcribed into cDNA using the MessageSensorTM RT kit (Ambion Inc.) as described previously [31]. Briefly, $5 \mu \mathrm{l}$ of RNA (50 ng/ $\mu \mathrm{l}$ ) was combined with $10 \times \mathrm{RT}$ buffer, dNTPs, $10 \mu \mathrm{M}$ random decamers, RNase Inhibitor, and M-MLV reverse transcriptase. RNA was reverse transcribed by incubating the samples at $25^{\circ} \mathrm{C}$ for 10 minutes, $42^{\circ} \mathrm{C}$ for 60 minutes, and $95^{\circ} \mathrm{C}$ for 10 minutes. cDNA was used immediately for real time PCR analysis.

\section{Real-time PCR expression of mRNAs in fetal gonads}

The relative expression level of mRNAs involved in fetal gonadal development (ESR1, ESR2, CYP19, SOX9,
WNT4, FST) and two housekeeping genes (GAPDH and RN18S) was examined using real-time PCR. Preliminary experiments in our laboratory revealed the expression level of these two housekeeping genes were consistent and did not change. Gene specific primers were designed using Primer3 [32] using ovine, bovine, and/or porcine sequences (see Additional file 2, Table S2). Amplification efficiencies were determined using a 10 fold serial dilution series of a GD75 XX and XY gonadal cDNA pool for each primer set. In addition, cDNA products were sequenced to validate primer specificity.

Analysis was performed in $10 \mu \mathrm{l}$ reactions containing $2 \times$ SYBR Green Master Mix I (Roche Applied Sciences), $0.5 \mu \mathrm{M}$ gene specific forward and reverse primer, and cDNA (diluted 1:4) using the LightCycler480 PCR system. The reaction conditions were as follows: $95^{\circ} \mathrm{C}$ for $5 \mathrm{~min}$ utes and then 45 cycles of $95^{\circ} \mathrm{C}$ for 10 seconds, $60^{\circ} \mathrm{C}$ for 30 seconds, and $72^{\circ} \mathrm{C}$ for 30 seconds followed by a melt curve analysis, to confirm amplification of single PCR products. This experiment was repeated twice $(n=2-4)$. Relative expression level of transcripts was determined by calculating the geometric mean of GAPDH and RN18S expression values, and using this as a normalization factor. Statistical differences were assessed at $\mathrm{P}<0.05$ using a Students t-test. PCR amplification efficiencies were between $1.8-2.1$, and relative expression levels were presented by plotting mean $2^{-\Delta \mathrm{Cp}}$ values [33].

\section{Histology}

Fixed fetal gonads were dehydrated and paraffin embedded using routine procedures. $5 \mu \mathrm{m}$-thick tissue sections were cut and stained with hematoxylin and eosin, and examined using a light microscope equipped with plan apochromatic objectives. Additional 4\% paraformaldehyde fixed, unstained $5 \mu \mathrm{m}$ GD75 and GD90 tissue sections were provided by Dr. Peter Smith (AgResearch Limited, Invermay, New Zealand) and used for in situ hybridization analysis.

\section{In situ hybridization}

Cellular localization of miR-22 was examined in GD75 and GD90 ovaries and testes using non-radioactive in situ hybridization. Non-radioactive in situ hybridization was performed using DIG labeled LNA miRNA probes for U6 (positive control), $m i R-22$, and a scramble (negative control) (Cat \# 99002-15, 300500-15, and 99004-01 respectively; Exiqon, Vedbaek, Denmark) according to the manufacturer's instruction and included a Tyramide Signal Amplification (TSA) step (Perkin-Elmer, Waltham, MA). Briefly, following deparaffinization with xylene, tissue sections were rehydrated through a graded series of ethanol washes $(100 \%, 70 \%, 50 \%, 25 \%)$, and rinsed in phosphate buffered saline (PBS). After endogenous peroxidase activity was blocked by incubating 
tissue sections in $0.03 \% \mathrm{H}_{2} \mathrm{O}_{2}$ (30 minutes) and proteins were digested with $10 \mu \mathrm{g} / \mathrm{ml}$ proteinase $\mathrm{K}$, tissue sections were washed and post-fixed in 4\% PFA, and incubated overnight in hybridization buffer (50\% deionized formamide, $5 \times$ SCC, $0.1 \%$ Tween $20,50 \mu \mathrm{g} / \mathrm{ml}$ heparin, and $50 \mu \mathrm{g} / \mathrm{ml}$ yeast tRNA). The next day, tissue sections were incubated overnight with hybridization buffer containing $0.25 \mu \mathrm{M}$ probe at $50^{\circ} \mathrm{C}$ in a humidified chamber. Following washes and incubation in blocking buffer $(2 \%$ sheep serum and $2 \mathrm{mg} / \mathrm{ml}$ BSA in PBS plus $0.01 \%$ Tween (PBST)), tissue sections were incubated in blocking buffer containing anti-DIG conjugated horseradish peroxidase (HRP) antibody (Abcam, Cambridge, MA; 1:2000 dilution) for 30 minutes at room temperature. TSA signal amplification was conducted by adding 100-300 $\mu \mathrm{l}$ fluophore tyramide solution per tissue section for 12 minutes at room temperature, followed by washes in PBST, and incubation with anti-fluorescein alkaline phosphatase (AP) conjugated antibody (Rockland Inc., Gilbertsville, PA; 1:75 dilution) for 30 minutes. Antibody staining was visualized using BCIP/NBT in AP buffer $(100 \mathrm{mM}$ Tris- $\mathrm{HCl}, 50 \mathrm{mM} \mathrm{MgCl} 2,100 \mathrm{mM}$ $\mathrm{NaCl}, 0.1 \%$ Tween 20, $2.4 \mathrm{mg}$ Levamisole (Honeywell, Seelze, Germany)). Color development was monitored and stopped by washing the slides in PBST (5 hours for U6, 48 hours for $m i R-22$ and scramble).

\section{Results}

\section{MiRNA expression in fetal gonads}

Using a custom designed 128-miRNA profiler PCR plate, the relative expression level of 128 conserved miRNA sequences was assessed in sheep fetal gonads. At GD42, when testicular cords develop in XY gonads (Figure 1), 24 miRNAs exhibited a sexual dimorphic expression pattern with at least 2 fold difference (Table 1). Of these, 12 miRNAs were expressed significantly higher in $\mathrm{XX}$ and 12 were expressed significantly higher in $\mathrm{XY}$ gonads. At GD75, when the ovary is filled with ovigerous cords (Figure 1) and primordial follicles start to form, $43 \mathrm{miR}$ NAs exhibited a sexually dimorphic expression pattern with at least a 2 fold change; 26 miRNAs were expressed significantly higher in GD75 ovaries, and 17 were expressed significantly higher in GD75 testes (Table 2).

In addition to identifying miRNAs exhibiting sexual dimorphic expression patterns, relative expression level of miRNAs was examined during development within fetal ovaries and fetal testes by comparing miRNA expression in GD42 and GD75 gonads. Comparing miRNA expression in GD42 and GD75 ovaries, 62 miRNAs with at least a 2 fold change were differentially expressed; 31 were expressed significantly higher in GD42 ovaries and 31 were expressed significantly higher in GD75 ovaries (Table 3). Within fetal testes, 30 miRNAs with at least a 2 fold change were expressed differentially when comparing
GD42 to GD75; 13 were expressed significantly higher in GD42 testes and 17 were expressed significantly higher in GD75 testes (Table 3).

To gain further insight into the possible function of these miRNAs, TargetScan 5.1, Meta Mir:Target Inference, and miRGator [34-36] were used as tools to identify potential genes known to be involved in mammalian fetal gonadal differentiation targeted by miRNAs. Examining the differentially expressed miRNAs in GD42 gonads revealed a number of genes, including SOX9, ESR1 (estrogen receptor 1), and CYP19A1 (cytochrome P450, family 19 , subfamily a, polypeptide 1 ) as potential targets (Table 4). Furthermore, differently expressed miRNAs in GD75 ovaries and testes are predicted to target a number of genes including ESR1, CYP19A1, FST (follistatin), and WNT4 (Table 4).

\section{Expression of CYP19A1, FST, ESR1, ESR2, SOX9, and WNT4 in fetal gonads}

Expression level of a number of key genes ( $S R Y$, CYP19A1, AMH (anti-Mullerian hormone), SF1, and WT1 (Wilms tumor 1 homolog)) involved in fetal gonadal sex determination has been examined previously during early gonadal differentiation in sheep [37]. We confirm and extend these observations by determining the expression level of CYP19A1, FST, ESR1, ESR2, SOX9, and WNT4. Real time PCR analysis revealed that CYP19A1, ESR1, ESR2, WNT4 and FST were significant more highly expressed in ovaries compared to testes at both GD42 (Figure 2) and GD75 (Figure 3), whereas SOX9 was significant more highly expressed in testes compared to ovaries (Figure 2 and 3 ).

\section{MiRNA target and functional enrichment analysis}

The database miRGator [36] was used to perform functional enrichment analysis of predicted miRNA targets during fetal ovarian and testicular development. For this analysis, the 10 differently expressed miRNAs exhibiting the greatest fold changes (GPR score $>0.400$ ) between GD42 and GD75 (Table 1 and 2) were examined using the Target-Function-Expression module. During fetal ovarian and testicular development, pathways involving MAPKinase signaling, cell cycle, G-protein signaling, proteasome degradation \& complex, and phospholipids as signaling intermediates are targeted more frequently by miRNAs at GD75 compared to GD42 (Table 5). Glycolysis and gluconeogenesis, and cytokines and inflammatory response pathways are targeted more frequently at both GD42 and GD75 during fetal ovarian development, whereas the WNT signaling pathway is targeted more frequently by miRNAs during fetal testicular development. Finally, regulation of ER activity is targeted by miRNAs more frequently in GD42 compared to GD75 ovaries. 


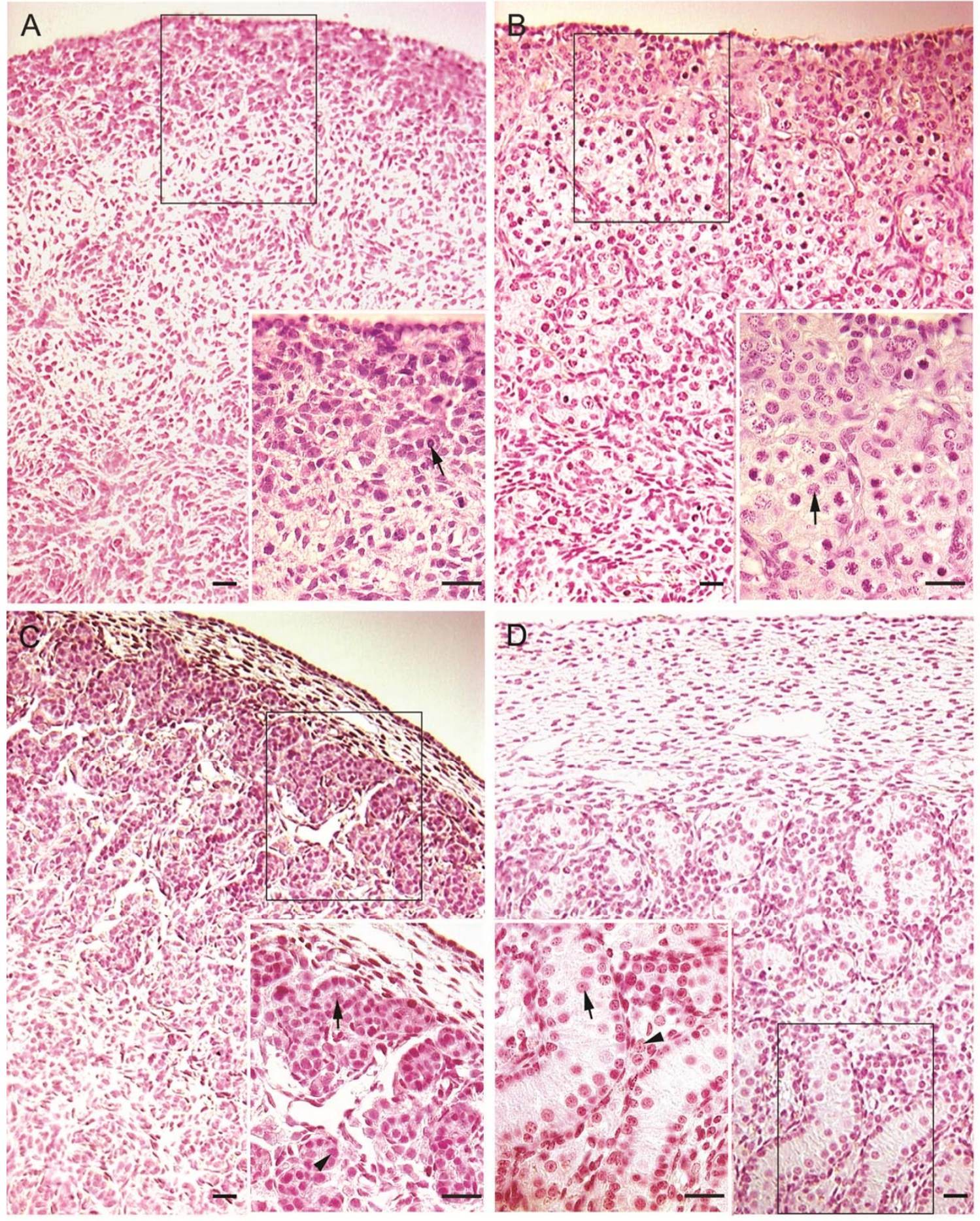

Figure 1 Tissue sections of GD42 and GD75 ovaries and testes stained with hematoxylin and eosin. A) GD42 ovary illustrating a thin ovarian cortex containing oogonia and precursor granulosa cells. Arrow in insert points to an oogonium. B) GD75 ovary illustrating a thickened cortex containing ovigerous cords. Arrow in insert depicts oocyte within an ovigerous cord. C) GD42 testis demonstrating presence of testicular cords containing gonocytes and Sertoli cells. Arrow in insert points to a gonocyte; arrowhead points to a Sertoli cell nucleus. D) GD 75 testis revealing prominent testicular cords. Arrow in insert points to a gonocyte; arrowhead points to an interstitial (Leydig) cell. All bars are $20 \mu \mathrm{m}$. 
Table 1 Significant differently expressed miRNAs exhibiting a fold change $>2$ in GD42 sheep ovaries and testes, according to real time RT-PCR analysis

\begin{tabular}{|c|c|c|}
\hline miRNA & GPR Score & Fold-Change \\
\hline \multicolumn{3}{|c|}{ Significantly higher in GD42 ovary } \\
\hline miR-431 & 0.836 & 5.35 \\
\hline let-7c & 0.789 & 3.98 \\
\hline $\operatorname{miR}-328$ & 0.688 & 3.85 \\
\hline miR-195 & 0.734 & 3.59 \\
\hline miR-486 & 0.695 & 3.40 \\
\hline let-7d & 0.727 & 3.13 \\
\hline miR-7 & 0.594 & 3.07 \\
\hline miR-484 & 0.672 & 2.99 \\
\hline $\operatorname{miR}-423$ & 0.656 & 2.81 \\
\hline let-7a & 0.703 & 2.75 \\
\hline $\operatorname{miR}-320$ & 0.531 & 2.67 \\
\hline let-7e & 0.586 & 2.23 \\
\hline \multicolumn{3}{|c|}{ Significantly higher in GD42 testis } \\
\hline $\operatorname{miR}-758$ & 0.734 & 5.00 \\
\hline miR-192 & 0.844 & 4.50 \\
\hline miR-223 & 0.797 & 3.74 \\
\hline miR-101 & 0.477 & 2.74 \\
\hline miR-411 & 0.656 & 2.58 \\
\hline miR-369-5p & 0.523 & 2.55 \\
\hline miR-301 & 0.594 & 2.21 \\
\hline$m i R-142-5 p$ & 0.484 & 2.19 \\
\hline miR-27b & 0.516 & 2.19 \\
\hline miR-379 & 0.555 & 2.18 \\
\hline miR-142-3p & 0.484 & 2.08 \\
\hline miR-376a & 0.414 & 2.04 \\
\hline
\end{tabular}

Significance (indicated by GPR score) and fold change were determined using Global Pattern Recognition v2.0.

Cellular localization of miR-22 in fetal sheep gonads

Estrogen signaling plays an important role during sheep ovarian development $[27,38,39]$. In situ hybridization was conducted to examine the localization of $m i R-22$, predicted to target ESR1 in fetal sheep gonads. MiR-22 is down-regulated during fetal ovarian development (GPR score 0.953, 1900 fold; Table 3) and up-regulated during testicular development (GPR score 0.500, 2.6 fold; Table 3), according to real time PCR. Using a LNA-modified probe specific to miR-22, in situ hybridization analysis revealed specific localization of $m i R-22$ in Sertoli cells within testicular cords of GD90 testis sections, but not GD75 testis sections (Figure 4). No staining was observed within ovaries, or when a scrambled miRCURY LNA detection probe was used.

\section{Discussion}

In mammals the activation of both fetal ovarian and testicular genetic pathways involve dynamic changes in the
Table 2 Significant differently expressed miRNAs exhibiting a fold change $>2$ in GD75 sheep ovaries and testes, according to real time RT-PCR analysis

\begin{tabular}{|c|c|c|}
\hline miRNA & GPR Score & Fold-Change \\
\hline \multicolumn{3}{|c|}{ Significantly higher in GD75 ovary } \\
\hline let-7c & 0.953 & 100.07 \\
\hline $\operatorname{miR}-146 b$ & 0.781 & 18.52 \\
\hline miR-103 & 0.844 & 17.23 \\
\hline $\operatorname{miR}-125 b$ & 0.859 & 15.92 \\
\hline let-7d & 0.758 & 15.73 \\
\hline $\operatorname{miR}-484$ & 0.859 & 15.55 \\
\hline let-7a & 0.758 & 14.90 \\
\hline $\operatorname{miR}-25$ & 0.773 & 10.89 \\
\hline $\operatorname{miR}-125 a$ & 0.758 & 8.91 \\
\hline miR-99a & 0.805 & 8.78 \\
\hline $\operatorname{miR}-100$ & 0.828 & 8.39 \\
\hline $\operatorname{miR}-150$ & 0.664 & 6.25 \\
\hline $\operatorname{miR}-130 a$ & 0.734 & 5.76 \\
\hline miR-19b & 0.664 & 5.33 \\
\hline $\operatorname{miR}-28$ & 0.695 & 4.81 \\
\hline miR-362 & 0.602 & 4.68 \\
\hline $\operatorname{miR}-16$ & 0.484 & 4.35 \\
\hline miR-200c & 0.688 & 4.16 \\
\hline miR-200b & 0.688 & 4.11 \\
\hline miR-210 & 0.688 & 3.85 \\
\hline miR-19a & 0.555 & 3.59 \\
\hline miR-10a & 0.648 & 3.12 \\
\hline let-7g & 0.602 & 2.82 \\
\hline let-7e & 0.469 & 2.48 \\
\hline miR-92 & 0.430 & 2.42 \\
\hline miR-183 & 0.422 & 2.42 \\
\hline
\end{tabular}

Significantly higher in GD75 testis

$\begin{array}{lcc}\text { miR-22 } & 0.961 & 4223.97 \\ \text { miR-142-3p } & 0.922 & 23.40 \\ \text { miR-27a } & 0.734 & 7.77 \\ \text { miR-33 } & 0.719 & 6.04 \\ \text { miR-302d } & 0.727 & 5.24 \\ \text { miR-27b } & 0.672 & 4.65 \\ \text { miR-410 } & 0.508 & 3.81 \\ \text { miR-199b } & 0.492 & 3.78 \\ \text { miR-455 } & 0.570 & 3.27 \\ \text { miR-211 } & 0.547 & 3.22 \\ \text { miR-212 } & 0.422 & 3.15 \\ \text { miR-379 } & 0.523 & 3.02 \\ \text { miR-411 } & 0.453 & 2.86 \\ \text { miR-369-5p } & 0.531 & 2.67 \\ \text { miR-301 } & 0.453 & 2.63 \\ \text { miR-409-5p } & 0.445 & 2.30 \\ \text { miR-152 } & 0.484 & 2.03\end{array}$

Significance (indicated by GPR score) and fold change were determined using Global Pattern Recognition v2.0. 
Table 3 Significant differently expressed miRNAs exhibiting a fold change $\geq 2$ in GD42 and GD75 sheep ovaries and testes, according to real time RT-PCR analysis

\begin{tabular}{|c|c|c|c|c|c|c|c|c|}
\hline miRNA & GPR Score & Fold-Change & miRNA & GPR Score & Fold-Change & miRNA & GPR Score & Fold-Change \\
\hline \multicolumn{3}{|c|}{$\begin{array}{c}\text { Significantly higher in GD42 versus GD75 XX } \\
\text { gonads }\end{array}$} & \multicolumn{3}{|c|}{$\begin{array}{l}\text { Significantly higher in GD75 versus GD42 XX } \\
\text { gonads }\end{array}$} & \multicolumn{3}{|c|}{$\begin{array}{l}\text { Significantly higher in GD42 versus GD75 XY } \\
\text { gonads }\end{array}$} \\
\hline miR-22 & 0.953 & 1935.53 & let-7c & 0.883 & 46.01 & miR-302d & 0.891 & 16.36 \\
\hline miR-302d & 0.945 & 119.16 & $\operatorname{miR}-142-5 p$ & 0.898 & 35.40 & miR-200c & 0.867 & 11.85 \\
\hline miR-206 & 0.875 & 14.76 & miR-19b & 0.906 & 27.28 & miR-222 & 0.734 & 5.32 \\
\hline $\operatorname{miR}-222$ & 0.875 & 8.43 & miR-19a & 0.883 & 16.43 & miR-200b & 0.695 & 4.44 \\
\hline miR-196a & 0.844 & 7.40 & $\operatorname{miR}-135 a$ & 0.781 & 12.28 & miR-362 & 0.609 & 3.95 \\
\hline $\operatorname{miR}-328$ & 0.672 & 7.34 & $\operatorname{miR}-125 b$ & 0.883 & 12.18 & miR-99b & 0.539 & 3.95 \\
\hline $\operatorname{miR}-433$ & 0.781 & 7.23 & let-7a & 0.727 & 10.89 & $\operatorname{miR}-485-5 p$ & 0.578 & 3.61 \\
\hline miR-486 & 0.813 & 6.81 & miR-130a & 0.852 & 9.93 & miR-382 & 0.586 & 3.22 \\
\hline $\operatorname{miR}-216$ & 0.727 & 6.63 & miR-146b & 0.648 & 9.92 & miR-149 & 0.484 & 3.01 \\
\hline $\operatorname{miR}-221$ & 0.820 & 5.88 & miR-100 & 0.883 & 9.48 & miR-15b & 0.523 & 2.82 \\
\hline miR-196b & 0.758 & 5.69 & miR-99a & 0.859 & 8.91 & miR-92 & 0.430 & 2.72 \\
\hline miR-574 & 0.750 & 4.83 & let-7d & 0.453 & 8.76 & miR-17-5p & 0.484 & 2.27 \\
\hline miR-485-5p & 0.742 & 4.52 & miR-101 & 0.688 & 8.52 & miR-107 & 0.414 & 2.15 \\
\hline miR-7 & 0.727 & 4.45 & miR-484 & 0.750 & 5.00 & \multicolumn{3}{|c|}{$\begin{array}{l}\begin{array}{l}\text { Significantly higher in GD75 versus GD42 XY } \\
\text { gonads }\end{array}\end{array}$} \\
\hline$m i R-423$ & 0.617 & 4.39 & miR-150 & 0.750 & 4.66 & miR-142-3p & 0.938 & 15.89 \\
\hline$m i R-382$ & 0.680 & 3.76 & miR-30b & 0.758 & 4.41 & $\operatorname{miR}-142-5 p$ & 0.938 & 14.89 \\
\hline miR-134 & 0.656 & 3.57 & miR-103 & 0.664 & 4.32 & miR-33 & 0.922 & 11.50 \\
\hline $\operatorname{miR}-181 b$ & 0.703 & 3.54 & let-7g & 0.664 & 3.94 & miR-211 & 0.758 & 6.22 \\
\hline miR-200c & 0.625 & 2.99 & miR-497 & 0.773 & 3.82 & miR-193a & 0.633 & 4.21 \\
\hline miR-668 & 0.648 & 2.96 & miR-25 & 0.688 & 3.71 & miR-19b & 0.586 & 3.59 \\
\hline$m i R-149$ & 0.586 & 2.90 & miR-331 & 0.664 & 3.59 & miR-19a & 0.602 & 3.53 \\
\hline $\operatorname{miR}-379$ & 0.672 & 2.90 & miR-143 & 0.734 & 3.36 & miR-199b & 0.539 & 3.52 \\
\hline miR-598 & 0.656 & 2.55 & miR-199a & 0.695 & 3.18 & miR-27a & 0.406 & 3.35 \\
\hline miR-615 & 0.430 & 2.54 & miR-33 & 0.656 & 2.99 & miR-199a & 0.414 & 3.22 \\
\hline $\operatorname{miR}-214$ & 0.500 & 2.50 & miR-335 & 0.680 & 2.89 & miR-143 & 0.453 & 3.18 \\
\hline miR-539 & 0.656 & 2.40 & miR-21 & 0.680 & 2.84 & let-7g & 0.563 & 2.79 \\
\hline miR-652 & 0.453 & 2.35 & miR-15a & 0.648 & 2.76 & miR-22 & 0.500 & 2.62 \\
\hline $\operatorname{miR}-17-5 p$ & 0.578 & 2.31 & miR-148a & 0.641 & 2.31 & miR-30e-5p & 0.500 & 2.46 \\
\hline $\operatorname{miR}-15 b$ & 0.641 & 2.27 & let-7e & 0.492 & 2.31 & miR-204 & 0.414 & 2.27 \\
\hline miR-296 & 0.602 & 2.21 & miR-204 & 0.563 & 2.11 & miR-30b & 0.492 & 2.25 \\
\hline $\operatorname{miR}-212$ & 0.539 & 2.01 & miR-148b & 0.633 & 2.08 & let-7e & 0.430 & 2.16 \\
\hline
\end{tabular}

Significance (indicated by GPR score) and fold change were determined using Global Pattern Recognition v2.0.

Table 4 Selected miRNAs and their predicted gene targets according to TargetScan 5.1 [34] and Meta Mir: Target Inference (MAMI) [35]

\begin{tabular}{cc}
\hline Predicted Gene Target & miRNA \\
\hline CYP19 & Let7 $(a, c, d, e, g)$ \\
ESR1 & miR-22 \\
FOG2 (ZFPM2) & miR-200c, miR-142-5p, miR-302d \\
FOXL2 & miR-302d \\
FST & miR-410 \\
GATA4 & miR-200c \\
SOX9 & miR-101 \\
WNT4 & miR-211 \\
\hline
\end{tabular}

expression of hundred's of transcripts [10-14,40,41]. In this study we used sheep as an animal model to study the regulation of gene expression and function by miRNAs during fetal gonadal differentiation. Currently, only 4 miRNA sequences have been reported for sheep [29], however, miRNA sequences are highly conserved across species. Therefore, in order to examine miRNA expression in sheep fetal gonads, 128 miRNAs were selected that were expressed $(\mathrm{Cp}<37$; [31]) and demonstrated a single melt peak in a preliminary profiling experiment (see Additional file 1, Table S1).

Real time PCR analysis revealed that XX and XY fetal gonads contain significantly different amounts of several 


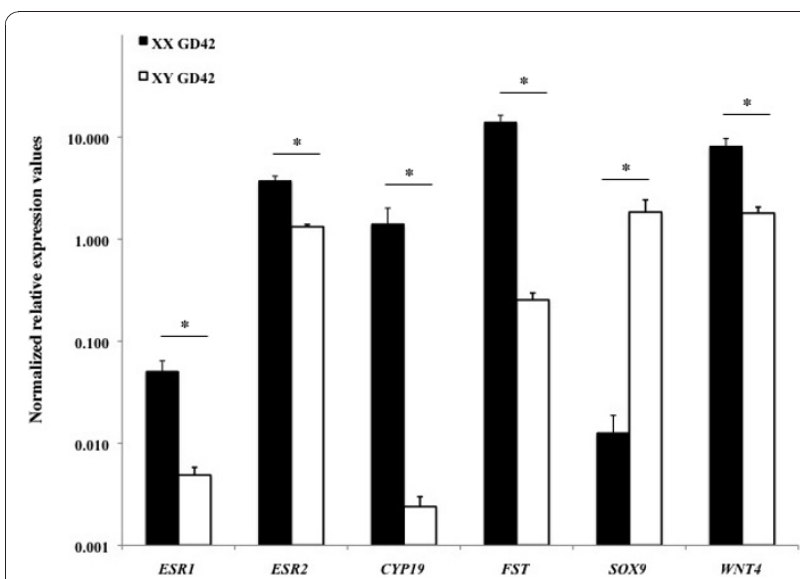

Figure 2 Relative expression level of ESR1, ESR2, CYP19A1, FST, SOX9, and WNT4 in GD42 ovaries and testes according to real time PCR analysis. ESR1, ESR2, CYP19A1, FST, and WNT4 were significantly (asterisk, $\mathrm{P}<0.05$ ) higher expressed in GD42 ovaries, whereas SOX9 was significantly (asterisk, $P<0.05$ ) higher expressed in GD42 testes. The $y$-axis indicates mean $2^{-\Delta C p}$ values ( \pm SEM) according to Schmittgen and Livak, 2008 [33].

miRNAs. At GD42, when fetal ovaries and testes differentiate, $m i R-101$ and several members of the Let7 family are preferentially expressed in testes and ovaries, respectively. One of the predicted targets of $m i R-101$ is SOX9, which is expressed at higher relative amounts in sheep fetal testes compared to ovaries, suggesting miR-101 regulates $S O X 9$ expression and/or function. Except for 137 bp (NCBI accession number AF012022), no SOX9 3'-UTR sequence is available for sheep. However, the 8

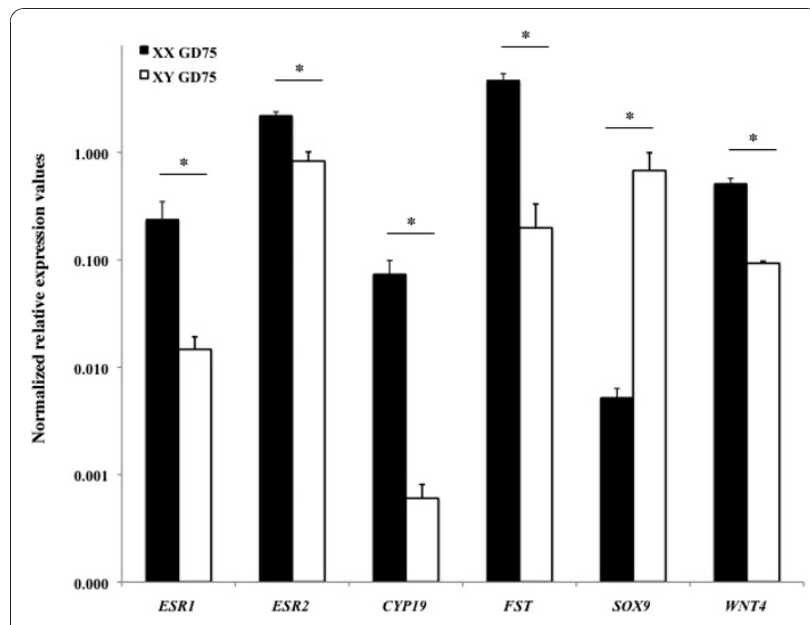

Figure 3 Relative expression level of ESR1, ESR2, CYP19, FST, SOX9, and WNT4 in GD75 ovaries and testes according to real time PCR analysis. ESR1, ESR2, CYP19A1, FST, and WNT4 were significantly (asterisk, $\mathrm{P}<0.05$ ) higher expressed in GD75 ovaries, whereas SOX9 was significantly (asterisk, $\mathrm{P}<0.05$ ) higher expressed in GD75 testes. The $y$-axis indicates mean $2^{-\Delta C p}$ values ( \pm SEM) according to Schmittgen and Livak, 2008 [33]. bp seed sequence of miR-101 predicted to target 3'UTR of SOX9 ( 450 bp down stream; 5'-GUACUGU-3') is conserved (TargetScan v5.1). It is unclear how $m i R-101$ regulates $S O X 9$ expression or function at the transcriptional and/or post-transcriptional level during fetal testicular development, but it is possible that miR-101 acts to fine-tune SOX9 expression [42].

In sheep, estrogen signalling plays a role during fetal ovarian development, and formation of primordial follicles ( GD75) may be dependent on estrogen and ESR1 signalling pathways [27,39]. CYP19A1 (aromatase) is expressed during fetal gonadal differentiation in ovaries and estrogen receptors (ESRs) are expressed as early as GD30 [37,39]. Similarly, recent studies in cows indicate that estrogen receptors and aromatase are expressed during the early stages of fetal ovarian development [43], further suggesting that estrogen signalling maybe important in fetal ovarian development in non-rodent mammalian species. MiRNA expression analysis revealed that Let7 and $m i R-22$ are preferentially expressed in GD75 ovaries and testes, respectively. Potential targets of Let7 and $m i R-22$ are CYP19A1 and ESR1 $(E R \alpha)$, respectively [34]. CYP19A1 is expressed during fetal ovarian development, whereas Let7 expression level is up-regulated in GD75 compared to GD42 ovaries. This suggests a possible role for Let7 in regulating CYP19A1 expression and/or function during fetal ovarian development. Similarly, $m i R-22$ expression is down-regulated possibly explaining increased ESR1 expression level during fetal ovarian development. Importantly, Pandey and Picard [44] recently demonstrated that $m i R-22$ targets and reduces ESR1 mRNA in breast cancer cells in vitro.

Contrary, in testes CYP19A1 and ESR 1 expression levels are significantly lower compared to ovaries at GD42 and GD75, whereas Let7e, Let7g, and miR-22 expression are significantly increased in GD75 compared to GD42 testes. To examine the cellular localization of $m i R-22$, LNA-modified probes and in situ hybridization was performed on GD75 testicular tissue sections. Although real time PCR indicated increased $m i R-22$ expression in GD75 testes, we were unable to detect $m i R-22$ using in situ hybridization at this stage. One possibility is that in situ hybridization was not sensitive enough to detect $m i R-22$ at this stage. Because GD90 tissue sections were available, we explored the possibility that $m i R-22$ can be detected by in situ hybridization at later stages of fetal gonadal development. MiR-22 localization was evident in GD90 testicular sections, and appeared to be confined within the testicular cords, localizing to the cytoplasm in Sertoli cells. Based on these results, we postulate that Sertoli cell development requires suppression of estrogen signalling during sheep testicular development involving $m i R-22$. 
Table 5 Functional enrichment analysis (miRGator; [36]) of predicted miRNA targets to uncover selected pathways targeted by miRNAs that are significantly more highly expressed in GD42 (downregulated) and GD75 (upregulated) ovaries and testes

\begin{tabular}{|c|c|c|c|c|}
\hline \multirow[t]{2}{*}{ Pathway } & \multicolumn{2}{|c|}{$\mathrm{XX}$} & \multicolumn{2}{|c|}{$\mathrm{XY}$} \\
\hline & GD42 & GD75 & GD42 & GD75 \\
\hline Cell Cycle & 13 & 20 & 15 & 20 \\
\hline Chromatin remodelling by hSWI/SNF ATP-dependent complexes & 3 & 1 & 2 & 5 \\
\hline Cytokine Network & 6 & 6 & 2 & 3 \\
\hline EGF signaling & 4 & 3 & 3 & 2 \\
\hline Electron Transport chain & 4 & 3 & 9 & 2 \\
\hline G-protein signaling & 8 & 16 & 6 & 15 \\
\hline Gap junction proteins connexins & 2 & 1 & 3 & 2 \\
\hline Glycolysis and gluconeogenesis & 4 & 3 & 1 & 1 \\
\hline Growth hormone signaling & 2 & 2 & 3 & 1 \\
\hline Insulin signaling & 3 & 4 & 4 & 2 \\
\hline MAPKinase signaling & 10 & 13 & 9 & 12 \\
\hline NGF pathway & 3 & 2 & 3 & \\
\hline PDGF signaling pathway & & 4 & 3 & 3 \\
\hline Phospholipids as signaling intermediates & & 6 & 1 & 4 \\
\hline Proteasome degradation & 1 & 7 & 1 & 6 \\
\hline Rac 1 cell motility signaling pathway & 1 & 3 & 3 & 2 \\
\hline Regulation ER & 5 & 2 & 1 & \\
\hline TGFbeta signaling pathway & & 2 & 1 & 3 \\
\hline TNFR Signaling & & 3 & & 3 \\
\hline Transcription factor CREB and its extracellular signals & 1 & 6 & 3 & 4 \\
\hline WNT signaling & 5 & 5 & 7 & 8 \\
\hline
\end{tabular}
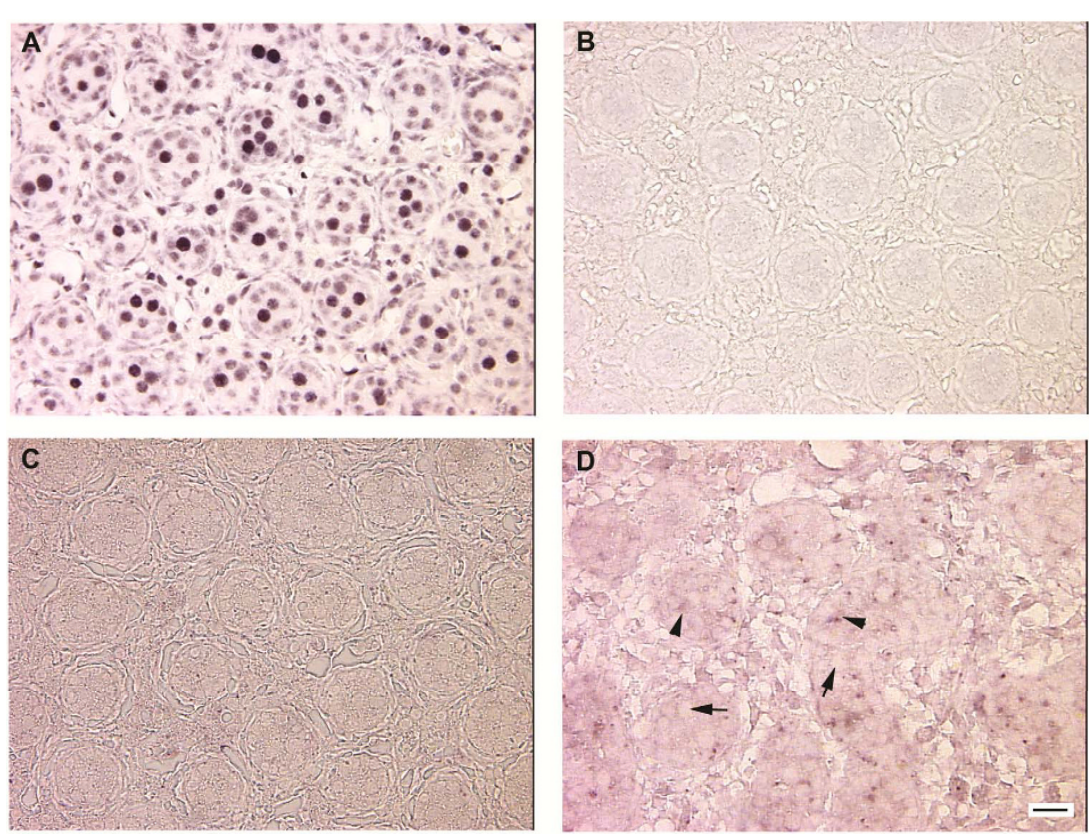

Figure 4 Tissue sections of GD75 and GD90 testes. A) GD75 testis section incubated with U6 control miRCURY LNA probe indicating positive ubiquitous staining in germ and somatic cells. B) GD75 testis section incubated with scrambled miRCURY LNA probe indicating absence of any staining. C) GD75 testis section incubated with miR-22 DIG labeled probe indicating no positive staining. D) GD90 testis section incubated with miR-22 DIG labeled probe. Arrows point to unstained gonocytes within testicular cords; arrowheads point to positive staining within testicular cords between gonocytes. All images were captured using a 40x objective, and the bar is $20 \mu \mathrm{m}$. 
MiRNA binding to 3'UTR target sequences occurs through complementary binding of the miRNA "seed" sequence (miRNA nucleotides 2-7). This partially explains how miRNAs potentially can regulate expression and/or function of more than one mRNA or whole signalling networks and complex biological processes. Using a bioinformatics approach we explored the possibility that the different biological processes or pathways underlying fetal ovarian and testicular development are regulated by miRNAs. This analysis revealed that estrogen signalling (regulation of ESR and modulation ESR activity) is targeted less frequently by miRNAs as fetal ovarian development proceeds. For example, during ovarian development (comparing GD42 to GD75 ovaries) the number of miRNAs targeting ESR function decreases, suggesting that estrogen function is necessary for proper ovarian and follicle development at GD75.

Another example of signalling pathways targeted by miRNAs in fetal sheep gonads is G-protein signalling (includes G-protein signalling, $G_{13}$ signalling pathway, signalling pathway from $G$ protein families). Both in fetal ovaries and testes, the number of miRNAs targeting G-protein signalling increases during gonadal development, suggesting that miRNAs potentially are involved in regulating G-protein signalling mediated functions during the latter stages of fetal gonadal development. G-protein signalling encompassing many different protein families and different cell signalling pathways is known to regulate reproduction at the hypothalamic, pituitary, and gonadal level [45]. During ovarian development G-protein-coupled receptor (GPR) 30, which has high affinity for estradiol, is involved in primordial follicle formation in hamster ovaries [46]. A predicted binding site for miR-130a (significant more highly expressed in GD75 compared to GD42 ovaries) is present within the 3'UTR of (human) GPR30.

Although this bioinformatics approach suggests the potential regulation of signaling pathways (or other biological processes) by miRNAs, future studies demonstrating direct interaction of selected miRNAs with their target sequences will need to be provided.

\section{Conclusions}

In summary, data presented in this study indicate that miRNAs are present during fetal gonadal development and differentiation in sheep. Based on the correlations observed between miRNA expression and their predicted targets, we postulate that miRNAs are important regulators of gene expression and function during fetal gonadal development. Similar to what has been proposed for the cow [47], the sheep is a useful model to study gonadal development and differentiation in mammals. For example, estrogen signalling appears to play a role in human, cow, and sheep fetal ovarian development $[38,39,43,48]$.
Based on our results, we further suggest that Let7 and $m i R-22$ regulate estrogen signalling during fetal sheep gonadal development, and $m i R-22$ may be necessary for suppressing the estrogen-signalling pathway during fetal testicular development. Finally, bioinformatic analysis revealed several pathways that are possibly regulated by miRNAs during fetal ovarian as well as testicular development.

\section{Additional material}

Additional file 1: Supplemental Table S1: The 128 mature miRNAs examined in this study. The mature miRNA sequence was used as the forward primer sequence in the real time PCR analysis.

Additional file 2: Supplemental Table S2: Gene specific primer sequences used to examine mRNAs by real time PCR.

\section{Acknowledgements}

The authors are especially indebted to Travis Antes for his help constructing the miRNA profiling plates. We are grateful to Scott Purcell for his help with sheep husbandry. Finally, we thank Brittany Fromme, Vanessa Enriquez, Samantha Roth, and Carol Moeller for their help in the lab. This project was supported by CSU-CVMBS Department of Biomedical Sciences and College Research Council (GJB).

\section{Author details}

${ }^{1}$ Animal Reproduction and Biotechnology Laboratory, Department of Biomedical Sciences, Colorado State University, Fort Collins, CO 80523, USA. ${ }^{2}$ AgResearch Limited, Invermay, Research Centre Mosgiel, New Zealand.

\section{Authors' contributions}

KJT and JCS performed the experiments, and DNRV helped with the immunohistochemistry analyses. PS, RVA, DNRV, and QAW provided reagents and materials. GJB designed the experiments, supervised the study, and wrote the manuscript. All authors read and approved the final manuscript.

\section{Competing interests}

The authors declare that they have no competing interests.

Received: 6 October 2010 Accepted: 11 January 2011

Published: 11 January 2011

\section{References}

1. Maatouk DM, Capel B: Sexual development of the soma in the mouse. Curr Top Dev Biol 2008, 83:151-183.

2. Sekido R, Lovell-Badge R: Sex determination and SRY: down to a wink and a nudge? Trends Genet 2009, 25:19-29.

3. Berta P, Hawkins JR, Sinclair AH, Taylor A, Griffiths BL, Goodfellow PN, Fellous M: Genetic evidence equating SRY and the testis-determining factor. Nature 1990, 348:448-450.

4. Gubbay J, Collignon J, Koopman P, Capel B, Economou A, Munsterberg A, Vivian N, Goodfellow P, Lovell-Badge R: A gene mapping to the sexdetermining region of the mouse $\mathrm{Y}$ chromosome is a member of a novel family of embryonically expressed genes. Nature 1990, 346:245-250.

5. Chassot AA, Ranc F, Gregoire EP, Roepers-Gajadien HL, Taketo MM, Camerino G, de Rooij DG, Schedl A, Chaboissier MC: Activation of betacatenin signaling by Rspo 1 controls differentiation of the mammalian ovary. Hum Mol Genet 2008, 17:1264-1277.

6. Tomizuka K, Horikoshi K, Kitada R, Sugawara Y, Iba Y, Kojima A, Yoshitome A, Yamawaki K, Amagai M, Inoue A, Oshima T, Kakitani M: Rspondin 1 plays an essential role in ovarian development through positively regulating Wnt-4 signaling. Hum Mol Genet 2008, 17:1278-1291.

7. Brennan J, Capel B: One tissue, two fates: molecular genetic events that underlie testis versus ovary development. Nat Rev Genet 2004, 5:509-521. 
8. Wilhelm D, Palmer S, Koopman P: Sex determination and gonadal development in mammals. Physiol Rev 2007, 1:1-28.

9. Yao HH, Matzuk MM, Jorgez CJ, Menke DB, Page DC, Swain A, Capel B: Follistatin operates downstream of Wnt 4 in mammalian organogenesis. Dev Dyn 2004, 230:210-215.

10. Small CL, Shima JE, Uzumcu M, Skinner MK, Griswold MD: Profiling gene expression during the differentiation and development of the murine embryonic gonad. Biol Reprod 2005, 72:492-501.

11. Nef S, Schaad O, Stallings NR, Cederroth CR, Pitetti JL, Schaer G, Malki S, Dubois-Dauphin M, Boizet-Bonhoure B, Descombes P, Parker KL, Vassalli JD: Gene expression during sex determination reveals a robust female genetic program at the onset of ovarian development. Dev Biol 2005, 287:361-377.

12. Beverdam A, Koopman P: Expression profiling of purified mouse gonadal somatic cells during the critical time window of sex determination reveals novel candidate genes for human sexual dysgenesis syndromes. Hum Mol Genet 2006, 15:417-431.

13. Bouma GJ, Affourtit JP, Bult CJ, Eicher EM: Transcriptional profile of mouse pre-granulosa and Sertoli cells isolated from early-differentiated fetal gonads. Gene Expr Patterns 2007, 7:113-123.

14. Bouma GJ, Hudson QJ, Washburn LL, Eicher EM: New candidate genes identified for controlling mouse gonadal sex determination and the early stages of granulosa and Sertoli cell differentiation. Biol Reprod 2010, 82:380-389.

15. Bartel DP: MicroRNAs: genomics, biogenesis, mechanism, and function. Cell 2004, 116:281-297.

16. Fazi F, Nervi C: MicroRNA: basic mechanisms and transcriptional regulatory networks for cell fate determination. Cardiovasc Res 2008, 79:553-561.

17. Fabian MR, Sonenberg N, Filipowicz W: Regulation of mRNA translation and stability by microRNAs. Ann Rev Biochem 2010, 79:351-379.

18. Lagos-Quintana M, Rauhut R, Yalcin A, Meyer J, Lendeckel W, Tuschl T: Identification of tissue-specific microRNAs from mouse. Curr Biol 2002, 12:735-739.

19. Hayashi K, Chuva de Sousa Lopes SM, Kaneda M, Tang F, Hajkova P, Lao K, O'Carroll D, Das PP, Tarakhovsky A, Miska EA, Surani MA: MicroRNA biogenesis is required for mouse primordial germ cell development and spermatogenesis. PLoS One 2008, 3:1738.

20. Maatouk DM, Loveland KL, McManus MT, Moore K, Harfe BD: Dicer1 is required for differentiation of the mouse male germline. Biol Reprod 2008, 79:696-703.

21. Papaioannou MD, Pitetti JL, Ro S, Park C, Aubry F, Schaad O, Vejnar CE, Kühne F, Descombes P, Zdobnov EM, McManus MT, Guillou F, Harfe BD, Yan W, Jegou B, Nef S: Sertoli cell Dicer is essential for spermatogenesis in mice. Dev Biol 2009, 326:250-259

22. Nagaraja AK, Andreu-Vieyra C, Franco HL, Ma L, Chen R, Han DY, Zhu H, Agno JE, Gunaratne PH, DeMayo FJ, Matzuk MM: Deletion of Dicer in somatic cells of the female reproductive tract causes sterility. Mol Endocrinol 2008, 22:2336-2352.

23. Hong X, Luense LJ, McGinnis LK, Nothnick WB, Christenson LK: Dicer1 is essential for female fertility and normal development of the female reproductive system. Endocrinology 2008, 149:6207-6212.

24. Gonzalez G, Behringer RR: Dicer is required for female reproductive tract development and fertility in the mouse. Mol Reprod Dev 2009, 76:678-688.

25. Mishima T, Takizawa T, Luo SS, Ishibashi O, Kawahigashi Y, Mizuguchi Y, Ishikawa T, Mori M, Kanda T, Goto T, Takizawa T: MicroRNA (miRNA) cloning analysis reveals sex differences in miRNA expression profiles between adult mouse testis and ovary. Reproduction 2008, 136:811-822.

26. Tripurani SK, Xiao C, Salem M, Yao J: Cloning and analysis of fetal ovary microRNAs in cattle. Anim Reprod Sci 2010, 120:16-22.

27. Juengel JL, Sawyer HR, Smith PR, Quirke LD, Heath DA, Lun S, Wakefield St J, McNatty KP: Origins of follicular cells and ontogeny of steroidogenesis in ovine fetal ovaries. Mol Cell Endocrinol 2002, 191:1-10

28. Sawyer HR, Smith P, Heath DA, Juengel JL, Wakefield St J, McNatty KP: Formation of ovarian follicles during fetal development in sheep. Biol Reprod 2002, 66:1134-1150

29. miRBase. [http://www.mirbase.org/]

30. Akilesh S, Shaffer DJ, Roopenian D: Customized molecular phenotyping by quantitative gene expression and pattern recognition analysis. Genome Res 2003, 13:1719-1727.
31. Bouma GJ, Hart GT, Washburn LL, Recknagel AK, Eicher EM: Using real time RT-PCR analysis to determine multiple gene expression patterns during XX and XY mouse fetal gonad development. Gene Expr Patterns 2004, 5:141-149.

32. Primer3. [http://frodo.wi.mit.edu/primer3/]

33. Schmittgen TD, Livak KJ: Analyzing real-time PCR data by the comparative C(T) method. Nat Prot 2008, 3:1101-1108.

34. TargetScan 5.1. [http://www.targetscan.org]

35. Meta Mir:Target Inference (MAMI). [http://mami.med.harvard.edu].

36. miRGator. [http://genome.ewha.ac.kr/miRGator/].

37. Payen E, Pailhoux E, Merhi RA, Gianquinto L, Kirszenbaum M, Locatelli A, Cotinot C: Characterization of ovine SRY transcript and developmental expression of genes involved in sexual differentiation. Int J Dev Biol 1996, 40:567-575.

38. Quirke LD, Juenge JL, Tisda DJ, Lun S, Heath DA, McNatty KP: Ontogeny of steroidogenesis in the fetal sheep gonad. Biol Reprod 2001, 65:216-228.

39. Juengel JL, Heath DA, Quirke LD, MCNatty KP: Oestrogen receptor alpha and beta, androgen receptor and progesterone receptor mRNA and protein localisation within the developing ovary and in small growing follicles of sheep. Reproduction 2006, 131:81-92.

40. Clement TM, Anway MD, Uzumcu M, Skinner MK: Regulation of the gonadal transcriptome during sex determination and testis morphogenesis: comparative candidate genes. Reproduction 2007, 134:455-72.

41. Houmard B, Small C, Yang L, Naluai-Cecchini T, Cheng E, Hassold T, Griswold M: Global gene expression in the human fetal testis and ovary. Biol Reprod 2009, 81:438-443.

42. Baek D, Villén J, Shin C, Camargo FD, Gygi SP, Bartel DP: The impact of microRNAs on protein output. Nature 2008, 455:64-71.

43. Garverick HA, Juengel JL, Smith P, Heath DA, Burkhart MN, Perry GA Smith MF, McNatty KP: Development of the ovary and ontongeny of mRNA and protein for P450 aromatase (arom) and estrogen receptors (ER) alpha and beta during early fetal life in cattle. Anim Reprod Sci 2010, 117:24-33

44. Pandey DP, Picard D: miR-22 inhibits estrogen signaling by directly targeting the estrogen receptor alpha mRNA. Mol Cell Biol 2009, 29:3783-3790.

45. Heitman $L H$, lizerman AP: $G$ protein-coupled receptors of the hypothalamic-pituitary-gonadal axis: a case for Gnrh, LH, FSH, and GPR54 receptor ligands. Med Res Rev 2008, 28:975-1011.

46. Wang C, Prossnitz ER, Roy SK: G protein-coupled receptor 30 expression is required for estrogen stimulation of primordial follicle formation in the hamster ovary. Endocrinology 2008, 149:4452-4461.

47. Ross DG, Bowles J, Hope M, Lehnert S, Koopman P: Profiles of gonadal gene expression in the developing bovine embryo. Sex Dev 2009, 3:273-283

48. Pezzi V, Mathis JM, Rainey WE, Carr BR: Profiling transcript levels for steroidogenic enzymes in fetal tissues. J Steroid Biochem Mol Biol 2003, 87:181-189.

doi:10.1186/1477-7827-9-2

Cite this article as: Torley et al:: Expression of miRNAs in ovine fetal gonads: potential role in gonadal differentiation. Reproductive Biology and Endocrinology 2011 9:2.

\section{Submit your next manuscript to BioMed Central and take full advantage of:}

- Convenient online submission

- Thorough peer review

- No space constraints or color figure charges

- Immediate publication on acceptance

- Inclusion in PubMed, CAS, Scopus and Google Scholar

- Research which is freely available for redistribution 